\title{
$\mathrm{LiOH}$ ベースのジンケート溶液中における \\ アルミニウムの 2 回ジンケート前処理
}

\author{
安住和久*, 由桐拓真*, 瀬尾眞浩*, 田代雄彦**, 川島 敏**
}

\section{Double Zincate Pretreatment of Al Alloy in a LiOH-based Zincate Solution}

\author{
Kazuhisa AZUMI*, Takuma YUGIRI*, Masahiro SEO*, Katsuhiko TASHIRO** \\ and Satoshi KAWASHIMA**
}

\begin{abstract}
A double zincate pretreatment of $\mathrm{Al}$ for plating was investigated in a $\mathrm{LiOH}$-based zincate solution. The zinc deposition rate from the $\mathrm{LiOH}$-based zincate solution was lower than that from $\mathrm{NaOH}$ or $\mathrm{KOH}$-based solutions, resulting in decreased deposition of $\mathrm{Zn}$ and dissolution of the $\mathrm{Al}$ substrate. This phenomenon was interpreted as a large coordination number for water molecules to bond with $\mathrm{Li}^{+}$ions compared to $\mathrm{Na}^{+}$and $\mathrm{K}^{+}$in the zincate solutions. For a LiOH-based zincate solution at a concentration near the solubility limit of water, the concentration of free water molecules decreases due to a strong restriction around $\mathrm{Li}^{+}$ions. This situation results in a decrease of the activity coefficient of $\mathrm{OH}^{-}$which leads to dissolution of the $\mathrm{Al}$ substrate, and decreases the coordination number for water molecules to in relation to $\mathrm{Zn}(\mathrm{OH})_{4}{ }^{2-}$ ions to accelerate the electron transfer from and $\mathrm{Zn}$ deposition on the $\mathrm{Al}$ substrate. Addition of $\mathrm{Fe}$ (III) ions to the LiOH-based zincate solution increased the rate of $\mathrm{Zn}$ deposition, suggesting that the co-deposition of $\mathrm{Fe}$ obstruct the growth of $\mathrm{Zn}$ deposition and results in imperfect insulation of the $\mathrm{Al}$ substrate by $\mathrm{Zn}$ deposition.
\end{abstract}

Key Words : Aluminum, Plating, Double Zincate, LiOH

\section{1. 緒言}

$\mathrm{Al}$ 合金に対するめつき前処理として, Al 表面を $\mathrm{Zn}$ で置換することによりめつきに適した均一な表面状態を 得る 2 回ジンケート法が用いられている ${ }^{1) ~ 7) 。 な わ ち, ~}$ 不均一な酸化物皮膜や合金成分, 研磨跡などに由来する 表面不均一性を有する $\mathrm{Al}$ 合金に対して 1 回目のジン ケート処理を行い, いったん析出した Zn を硝酸溶液中 で溶解した後, 2 回目のジンケート処理で均一な厚さの $\mathrm{Zn}$ 析出層を得る。このとき $\mathrm{Al}$ 表面は高濃度のアルカ リおよび酸により上述の不均一性が溶解除去されるとと もに，Znで表面が被覆されることにより高アルカリの ジンケート溶液中における $\mathrm{Al}$ の溶解が抑制される。ジ ンケート処理では, めっき層に対するアンカー性の良い 均一な $\mathrm{Zn}$ 析出層を得るとともに, 表面粗度の増加や廃 液処理の負担となる過㮃な $\mathrm{Al}$ 溶解を抑制するために, 濃度, 液温, 処理時間などの運転条件の管理が極めて重 要である。通常ジンケート溶液は $\mathrm{NaOH}$ をベースとし, $\mathrm{ZnO}$ および各種の金属イオンおよび錯化剂などの添加

* 北海道大学大学院 工学研究科 ( $\overline{\mathbf{T}} 060-8628$ 北海道札幌市 北区北 13 条西 8 丁目)

Graduate School of Eng., Hokkaido Univ. (N 13 W 8, Kita-ku, Sapporo-shi, Hokkaido 060-8628)

**メルテックス(㧣) 研究部 (テ330-0031 埼玉県大宮市吉野町 2-3-1)

Research and Development Dept., Meltex Inc. (2-3-1, Yoshino-cho, Omiya-shi, Saitama 330-0031)
剂を溶解させたものが用いられる4)。これら溶液の組成 は膨大な実験結果の蓄積と現実のめつきプラントの運転 実績により決定されてきたものである。

ハードディスクの記録密度が年々増加し, その結果 $\mathrm{A} 1$ 合金基板を用いたディスク材の平坦性や欠損などに 対する要求水準が高くなり，機械研磨に先立つめつき仕 上り段階での一層の品質向上が求められてきている また蒸着で作製した $\mathrm{Al}$ 薄膜に対するめっきなど, 応用 分野も広がっている。こうした背景から, 筆者らはジン ケート処理の特性をより広範に評価するため, $\mathrm{NaOH}$ 以外のアルカリ水溶液を用いて $\mathrm{Al}$ のジンケート処理を 行った。その結果, $\mathrm{LiOH}$ ベースのジンケート溶液中で ユニークな性質が見られたので報告する。

\section{2. 実験}

試料には純度 $99.999 \%$ Al 板を用いた。試料を適当 な大きさに切断後アセトン中で超音波洗浄し, 乾燥後表 1 に示したジンケート溶液に所定の時間浸漬して置換反

Table 1 Composition of zincate solutions.

\begin{tabular}{llll}
\hline Type & Base $/ \mathrm{g} \mathrm{dm}^{-3}$ & $\mathrm{ZnO} / \mathrm{g} \mathrm{dm}^{-3}$ & additive $/ \mathrm{g} \mathrm{dm}^{-3}$ \\
\hline A & $\mathrm{LiOH} \cdot \mathrm{H}_{2} \mathrm{O}, 240$ & 49 & non \\
B & $\mathrm{LiOH} \bullet \mathrm{H}_{2} \mathrm{O}, 80$ & 16 & non \\
C & $\mathrm{LiOH} \cdot \mathrm{H}_{2} \mathrm{O}, 240$ & 49 & $\mathrm{FeCl}_{3} \bullet 6 \mathrm{H}_{2} \mathrm{O}, 2$ \\
& & & potassium sodium tartrate, 6 \\
D & $\mathrm{NaOH}, 230$ & 50 & non \\
E & $\mathrm{KOH}, 321$ & 50 & non \\
& & & \\
\hline
\end{tabular}


応を行った。その後試料を純水およびエチルアルコール で洗浄・乾燥させ, 体積濃度 $50 \%$ の $\mathrm{HNO}_{3}$ 溶液に浸漬 して析出した $\mathrm{Zn}$ を溶解した。これをエチルアルコール で洗浄・乾燥したあと, ふたたびジンケート溶液に浸漬 して 2 回目の置換反応を行った。試料の浸漬中は溶液を かく找した。なおジンケート溶液は, $\mathrm{LiOH}$ の最大溶解 度程度 ${ }^{8)}$ に調整したものを溶液 $\mathrm{A}$ とし，これを $1 / 3$ に 希釈したものを溶液 $\mathrm{B}$ ，また他の溶液は溶液 $\mathrm{A}$ と同程 度のアルカリ濃度および $\mathrm{ZnO}$ 濃度となるように調整し た。置換反応時における試料の質量変化測定には電子天 科(島津製作所社製 $\mathrm{AG} 245$ 型, 感度 $0.01 \mathrm{mg}$ ), 置換反 応中の浸漬電位測定にはデジタルボルトメータ (Keith ley 社製 2000 型) とコンピュータ (Apple Computer 社製 Macintosh SE/30 型), 表面観察にはFE-SEM(日本電 子社製 JSM-6300 F 型)を用いた。なお，浸漬電位測定 は Zn を参照電極として，V vs. Zn として表記した。実 験はすべて室温 (約 $23^{\circ} \mathrm{C}$ )で行った。なお，測定方法お よび実験装置の詳細に関しては前報 ${ }^{2), 3)} に$ 記した。

\section{3．結果および考察}

\section{1 置換反応速度のアルカリ種に対する依存性}

$\mathrm{ZnO}$ を含む $\mathrm{LiOH}, \mathrm{KOH}$ およ゙ $\mathrm{NaOH}$ ベースのジ ンケート溶液中に打ける第 1 および第 2 ジンケート処理 中の $\mathrm{Zn}$ 析出量を図 1 a に示す。第 1 ジンケート処理に おける $\mathrm{Zn}$ 析出は第 1 段階の停滞, 第 2 段階の速い析出, 析出速度の低下した第 3 段階に分かれる。前報 ${ }^{2}$ におい て,これらの各段階は表面酸化物皮膜が化学溶解する第 1 段階, 下地 $\mathrm{Al}$ が現れて溶解し, 置換析出した Zn で 順次覆われて行く第 2 段階, 表面がほとんど $\mathrm{Zn}$ で覆わ れるが，下地からの $\mathrm{Al}$ 溶解が継続している第 3 段階と して解釈された。また第 2 ジンケート処理においては, 浸漬直後から第 1 ジンケート処理の第 3 段階に相当する 速度で $\mathrm{Zn}$ 析出が起こる。図 $1 \mathrm{a}$ では, 溶液 $\mathrm{D}(\mathrm{NaOH})$ および溶液 $\mathrm{E}(\mathrm{KOH})$ 中では同様な $\mathrm{Zn}$ 析出挙動を示し, また第 3 段階において Zn 析出が持続しているが，溶液 $\mathrm{A}(\mathrm{LiOH})$ 中では第 2 段階の開始に遅れが見られ，また 約 $60 \mathrm{~s}$ 以降の第 3 段階では $\mathrm{Zn}$ 析出速度が非常に小さい ことがわかる。第 2 ジンケート処理時でも同様に, 溶液 $\mathrm{A}$ 中における $\mathrm{Zn}$ の析出速度は他の溶液中よりも小さい。

図 $1 \mathrm{~b}$ に示したジンケート処理中の浸漬電位は, 第 1 ・第 2 段階では卑側にシフトし，第 3 段階では -10 〜 $18 \mathrm{mV}$ 付近に落ち着くが, 溶液 $\mathrm{A}$ 中では他の溶液 に比べて電位の変化に遅れのあることが明瞭である。こ れは，溶液 $\mathrm{A}$ 中における $\mathrm{Al}$ 酸化物皮膜および $\mathrm{Al}$ の溶 解速度が他の溶液中よりも遅いためであろう。

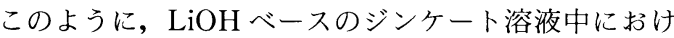
る $\mathrm{Zn}$ 析出挙動は, $\mathrm{NaOH}$ および $\mathrm{KOH}$ お゙ースのジン ケート溶液とはかなり異なる。そこで $\mathrm{LiOH}$ ベースの
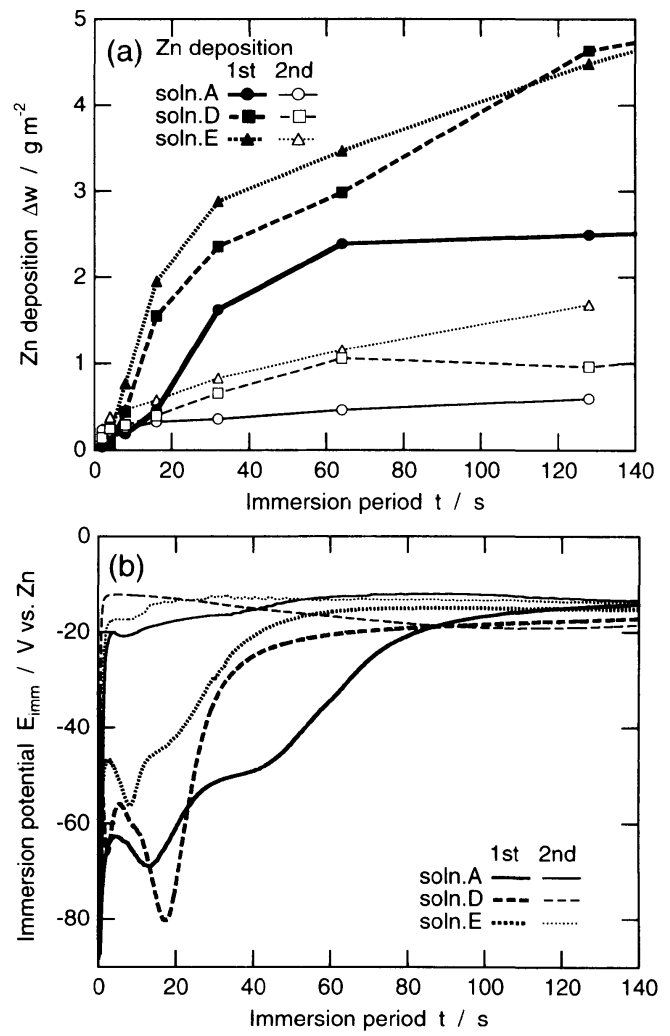

Fig. $1 \mathrm{Zn}$ deposition on $\mathrm{Al}$ (a) and immersion potential (b) during the 1 st and the 2 nd zincate processes in zincate solutions $\mathrm{A}, \mathrm{D}$, and $\mathrm{E}$ as a function of immersion period.

ジンケート溶液中の挙動をさらに詳細に調べた。図 2 に 溶液 $\mathrm{A}, \mathrm{B}, \mathrm{C}$ 中におけるジンケート処理の結果を示す。 図 $2 \mathrm{a}$ の質量変化では, 溶液 $\mathrm{A}$ 中における $\mathrm{Zn}$ 析出量は $\mathrm{LiOH}$ 抢よび $\mathrm{ZnO}$ 濃度が相対的に小さい溶液 $\mathrm{B}$ 中より も小さい。アルカリ濃度が高くなると Zn 析出量が低下 することは以前より報告されている リ濃度では置換反応速度が増加し, 短時間で $\mathrm{Al}$ 表面が $\mathrm{Zn}$ で被覆されて $\mathrm{Al}$ 溶解が抑制されるためと思われる。 $\mathrm{Fe}$ (III) を含む溶液 C中では第 1 および第 2 ジンケート 処理ともに置換反応速度が大きかった。また，図 2 a の 浸漬電位変化では, 溶液 $\mathrm{C}$ 中の第 1 ジンケート処理に

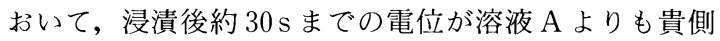
であった。こうした違いは，Feの酸化還元電位 $\left(\mathrm{E}\left(\mathrm{Fe}^{2+} / \mathrm{Fe}\right)=-0.440 \mathrm{~V}\right.$ vs. $\left.\mathrm{SHE}\right)$ が $\mathrm{Zn}\left(\mathrm{E}\left(\mathrm{Zn}^{2+} /\right.\right.$ $\mathrm{Zn})=-0.763 \mathrm{~V}$ vs. SHE) よりも貴であることから, 置 換反応中に $\mathrm{Al}$ 上および $\mathrm{Zn}$ 上に $\mathrm{Fe}$ が析出し, 試料の表 面状態を変えるためと思われる ${ }^{1} 。$ 筆者らはEDS 測定 より $\mathrm{Zn}$ 上に $\mathrm{Fe}$ が共析することを確認している ${ }^{3)}$ 。析出 した Fe は $\mathrm{Zn}$ 析出物をち密化して無電解 $\mathrm{Ni}$ めっき層に 対するアンカー効果を高め, 基板とめつき層との密着性 

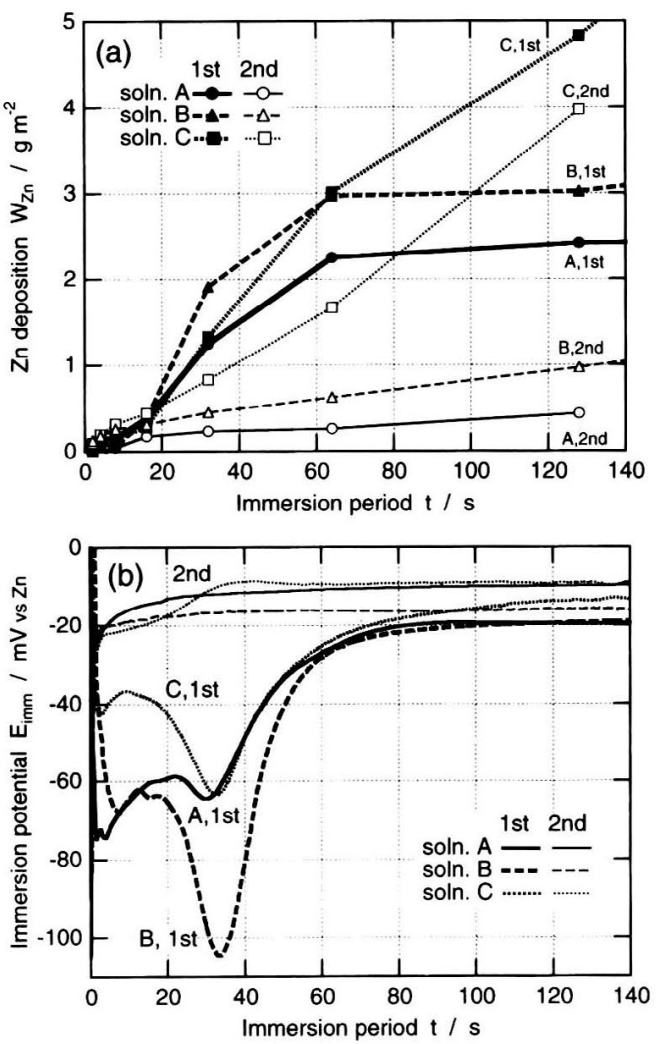

Fig. 2 Zn deposition on $\mathrm{Al}$ (a) and immersion potential (b) as a function of immersion period during the 1 st and the 2 nd zincate processes in zincate solutions $\mathrm{A}, \mathrm{B}$, and $\mathrm{C}$.

を向上させる作用があるとされる は, $\mathrm{NaOH}$ ベースのジンケート溶液中に Fe(III)が含ま れると $\mathrm{Al}$ 溶解反応の過電圧が大きくなり, 結果的に $\mathrm{Zn}$ 析出反応との混成電位が貴側にシフトすることを報 告したが,これはおそらく $\mathrm{Al}$ 上に析出した $\mathrm{Fe}$ が $\mathrm{Al} の$ 溶解反応に影響を与えたためであろう。 $\mathrm{Fe}$ (III) は, 後 の SEM 像に示すように, $\mathrm{LiOH}$ ベースのジンケート溶 液中における $\mathrm{Zn}$ の析出形態にも影響を与えている。

\section{2 置換反応時の $\mathrm{Al}$ 表面 SEM 像}

図 3 に溶液 A 中で所定の時間ジンケート処理した際 の $\mathrm{Al}$ 表面の $\mathrm{SEM}$ 像を示す。 $16 \mathrm{~s}$ 程度までは表面の 所々に微小な $\mathrm{Zn}$ 粒子が見られる。32sでは全面が微小

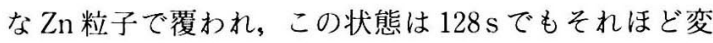
わらない。前報21.3) で, $\mathrm{NaOH}$ ベースのジンケート溶液 中における第 1 ジンケート処理時では, $\mathrm{Al}$ 表面にさま ざまなサイズの Zn 粒子が成長する様子を示した。これ

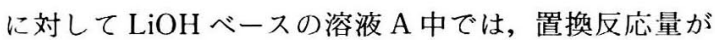
小さいために大きな $\mathrm{Zn}$ 粒子の成長が見られない。また $60 \mathrm{~s}$ 以降の置換反応速度が極めて小さいことから, 析出 した $\mathrm{Zn}$ は下地 $\mathrm{Al}$ 表面をほぼ完全に被覆していると推
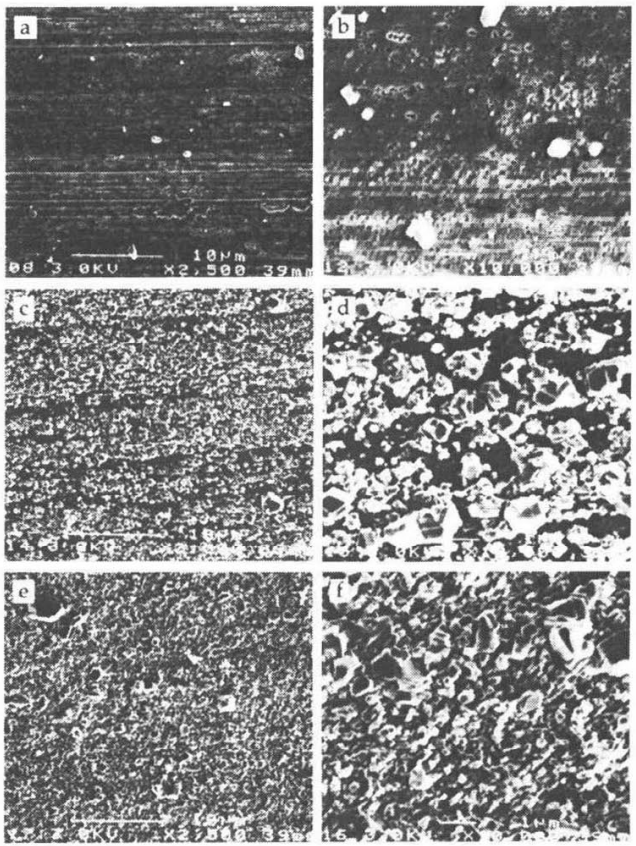

Fig. 3 SEM images of $\mathrm{Al}$ surface after the 1 st zincate process for (a,b) $16 \mathrm{~s}$, (c,d) $32 \mathrm{~s}$ and $(\mathrm{e}, \mathrm{f}) 128 \mathrm{~s}$ in zincate solution $\mathrm{A}$.
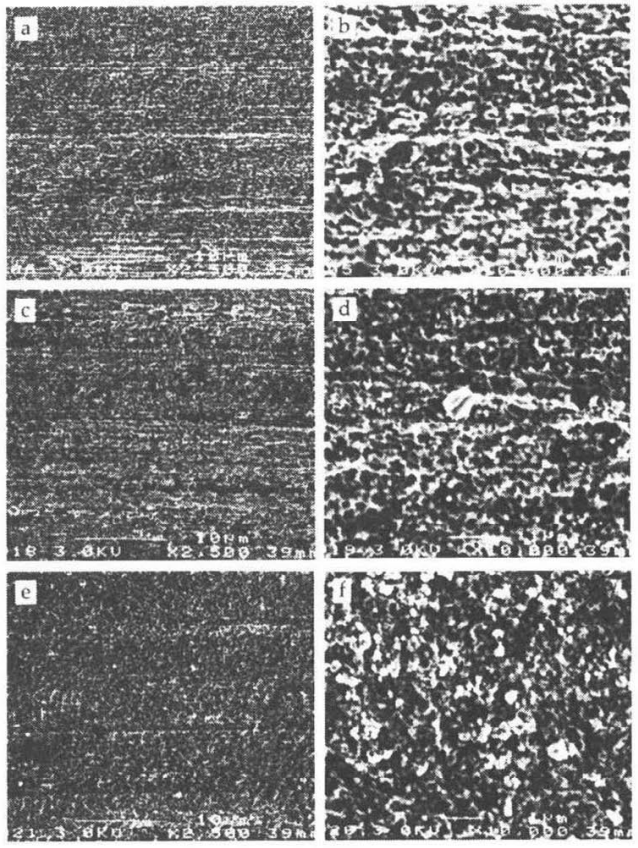

Fig. 4 SEM images of $\mathrm{Al}$ surface after $\mathrm{Zn}$ stripping for $30 \mathrm{~s}$ in 50 volume\% $\mathrm{HNO}_{3}$ solution (a,b), 2 nd zincate process for (c,d) $1 \mathrm{~s}$ and $(\mathrm{e}, \mathrm{f}) 32 \mathrm{~s}$ in zincate solution A following the 1 st zincate process for $60 \mathrm{~s}$. 

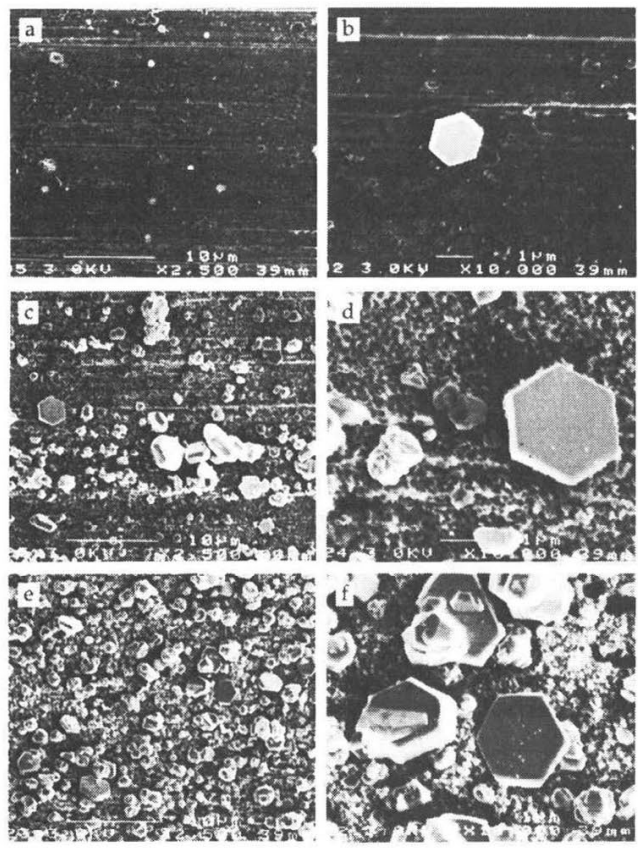

Fig. 5 SEM images of Al surface after the 1 st zincate process for $(\mathrm{a}, \mathrm{b}) 16 \mathrm{~s},(\mathrm{c}, \mathrm{d}) 32 \mathrm{~s}$ and $(\mathrm{e}, \mathrm{f}) 128 \mathrm{~s}$ in zincate solution $B$.

定される。

第 1 ジンケート処理を $60 \mathrm{~s}$ 行った後に試料を硝酸水 溶液に浸漬して $\mathrm{Zn}$ ストリッピングを行い, 続いて第 2 ジンケート処理を行った際の SEM 像を図 4 に示す。Zn 溶解後の表面には $\mathrm{Al}$ 溶解跡が見られる。この表面は酸 化物皮膜が非常に薄いため, 第 2 ジンケート処理開始後 ただちに置換反応が開始し, $1 \mathrm{~s}$ 程度でかなりの $\mathrm{Al}$ 表 面がち密な $\mathrm{Zn}$ 析出層で被覆されている様子がわかる。

図 $5 に, F e(I I I)$ を含む溶液 C 中で第 1 ジンケート処 理を行った際の SEM 像を示す。溶液 C 中では第 3 段階 でも置換反応が持続するため, $128 \mathrm{~s}$ 後では試料全面で $\mathrm{Zn}$ 粒子が成長している。しかし前報2)で示した $\mathrm{NaOH}$ ベースのジンケート溶液の場合と比較して Zn 粒子のサ イズが均一化しており，また平板的な形状の $\mathrm{Zn}$ 粒子が 目立つ。 $\mathrm{Fe}$ の共析が $\mathrm{Zn}$ の結晶成長を妨げることは前 述したが，その機構として Robertson ら ${ }^{10)}$ は, ジン ケート溶液中の $\mathrm{Fe}(\mathrm{III})$ が $\mathrm{Zn}$ 粒子端を置換溶解するこ とにより $\mathrm{Zn}$ の成長を抑制して $\mathrm{Zn}$ 粒子を微細化すると した。図 $5 \mathrm{f} の \mathrm{Zn}$ 粒子の端がいくぶん丸くなっている

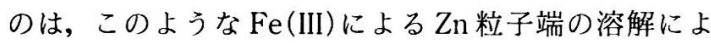
る可能性がある。しかしながら, $\mathrm{LiOH}$ と $\mathrm{NaOH} て ゙ ~ Z n$ 粒子の形状が異なる理由は不明である。図 2 に示したよ うに, 溶液 C中で第 3 段階でも置換反応が持続するの は, 浸漬初期に $\mathrm{Al}$ 表面に析出した $\mathrm{Zn}$ の成長が $\mathrm{Fe}$ 析出
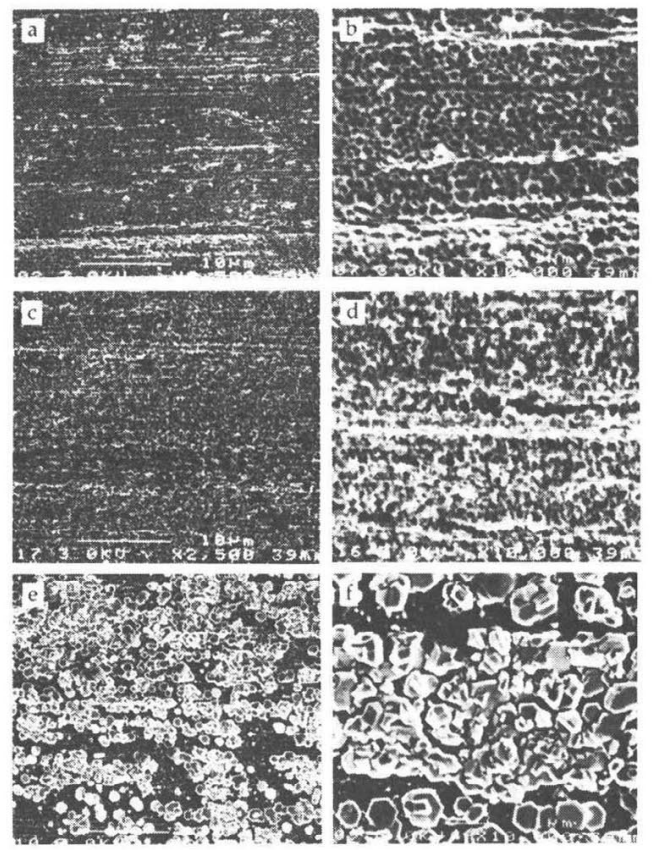

Fig. 6 SEM images of $\mathrm{Al}$ surface after $\mathrm{Zn}$ stripping for 30 $\mathrm{s}$ in 50 volume\% $\mathrm{HNO}_{3}$ solution (a,b), 2 nd zincate process for (c,d) $1 \mathrm{~s}$ and $(e, f) 32 \mathrm{~s}$ in zincate solution $\mathrm{B}$ following the $1 \mathrm{st}$ zincate process for $60 \mathrm{~s}$.

によって妨げられたために下地 $\mathrm{Al}$ 表面が完全に被覆さ れなかったためであろう。いったん下地 $\mathrm{Al} に$ 溶解穴が あいてその上を $\mathrm{Zn}$ 粒子が覆うと, 溶液バルクからの $\mathrm{Zn}(\mathrm{OH})_{4}{ }^{2-}$ が下地 $\mathrm{Al}$ に到達できなくなり, 溶解が持続 する ${ }^{3)}$ 。第 2 ジンケート処理時においても，Zn は微細な 粒子状に析出しており, 溶液 A とは異なる析出形態と なった。

\section{3. $3 \mathrm{LiOH}$ ベースのジンケート溶液中で置換反応速 度が異なる理由}

上に示したようなジンケート溶液による置換反応挙動 の相違は,アルカリ金属イオン種のどのような違いに よってもたらされるのであろうか。水に対する $\mathrm{LiOH}$ の溶解度は $\mathrm{KOH}$ あるいは $\mathrm{NaOH}$ に比べてかなり小さ い(表 2 )。これらの溶質の最大溶解度を決める因子は溶 媒和能, すなわち各アルカリ金属イオンが溶解状態を維

Table 2 Solubility of alkaline species to water at $273 \mathrm{~K}$ and cordination number of $\mathrm{H}_{2} \mathrm{O}$ molecular at maxi. mum concentrations.

Solubility g/ $100 \mathrm{~g} \mathrm{H}_{2} \mathrm{O} \quad \mathrm{H}_{2} \mathrm{O}$ cordination number

$\begin{array}{lcc}\mathrm{NaOH} & 53.3 & 1.94 \\ \mathrm{KOH} & 54.2 & 2.63 \\ \mathrm{LiOH} & 11.14 & 10.60\end{array}$


(a) $\mathrm{LiOH}$ solution (Satu.)

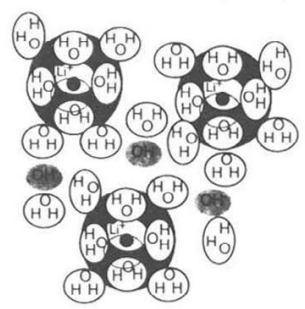

$\mathrm{NaOH}$ solution (non-Satu.)
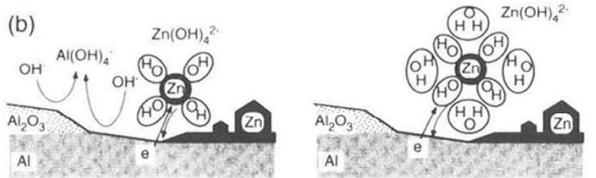

Fig. 7 Schematic representation of structure of aqueous solutions containing (a) $\mathrm{LiOH}$ and (b) $\mathrm{NaOH}$ at a concentration near the maximum solubility of LiOH.

持するのに最低限必要な水分子の配位数であろう。表 2 に各溶質の最大濃度における水分子の予想される配位数 を示した。イオン径の小さな $\mathrm{Li}^{+}$の配位数が最も多い。 別な表現を使うと, $\mathrm{Li}^{+}$は配位子として自身の周囲に拘 束している水分子が最も多い。本研究で用いた溶液 $\mathrm{A}$

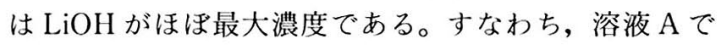
はほとんどの水分子が $\mathrm{Li}^{+}$に配位して拘束されている状 態にあると推定される。これに対して溶液 D, Eでは $\mathrm{NaOH}$ あるいは $\mathrm{KOH}$ が最大濃度に満たないため, 配 位水分子のほかに自由水分子が相当程度存在していると 思われる。この様子を図 $7 \mathrm{a} に$ 模式的に示した。

さて,このような水の構造が置換反応にどのような影 響を与えるであろうか。濃厚 $\mathrm{LiOH}$ 水溶液では, 水の 構造化にともない $\mathrm{OH}^{-}$の活量係数が低下するため, $\mathrm{Al}$ 酸化物および $\mathrm{Al}$ の溶解速度が低下寸る。実際溶液 $\mathrm{A}$ と 同濃度の $\mathrm{LiOH}$ 水溶液中における $\mathrm{Al}$ の溶解速度を測定 すると, $\mathrm{NaOH}$ 水溶液中の 0.6 倍程度であった。これ は図 1，2 に示した溶液 A 中における置換反応の遅れ を説明するものである。また, 溶液 $\mathrm{A}$ 中では第 1 ジン ケート処理の第 3 段階において下地 $\mathrm{Al}$ がほぼ完全に $\mathrm{Zn}$ で被覆されて置換速度が低下することから, 溶液 $\mathrm{A}$ 中ではいったん金属 $\mathrm{Al}$ 表面が露出すると $\mathrm{Zn}$ の析出が 迅速に起こると推定される。水溶液中の $\mathrm{Zn}(\mathrm{OH})_{4}{ }^{2-}$ に は水分子が配位していると思われるが, これが $\mathrm{Al}$ 表面 に到達して析出するためには, 配位している水分子を押 し退けて電子移動が可能な距離まで接近しなければなら ない(図 7 b)。一方濃厚 $\mathrm{LiOH}$ 水溶液中では自由水分 子の濃度が少ないため $\mathrm{Zn}(\mathrm{OH})_{4}{ }^{2-}$ に配位することがで きず, $\mathrm{Zn}(\mathrm{OH})_{4}{ }^{2-}$ は容易に $\mathrm{Al}$ 表面に接近して析出でき る可能性がある。

以上のようなモデルに基づけば， $\mathrm{NaOH}$ ベースのジ
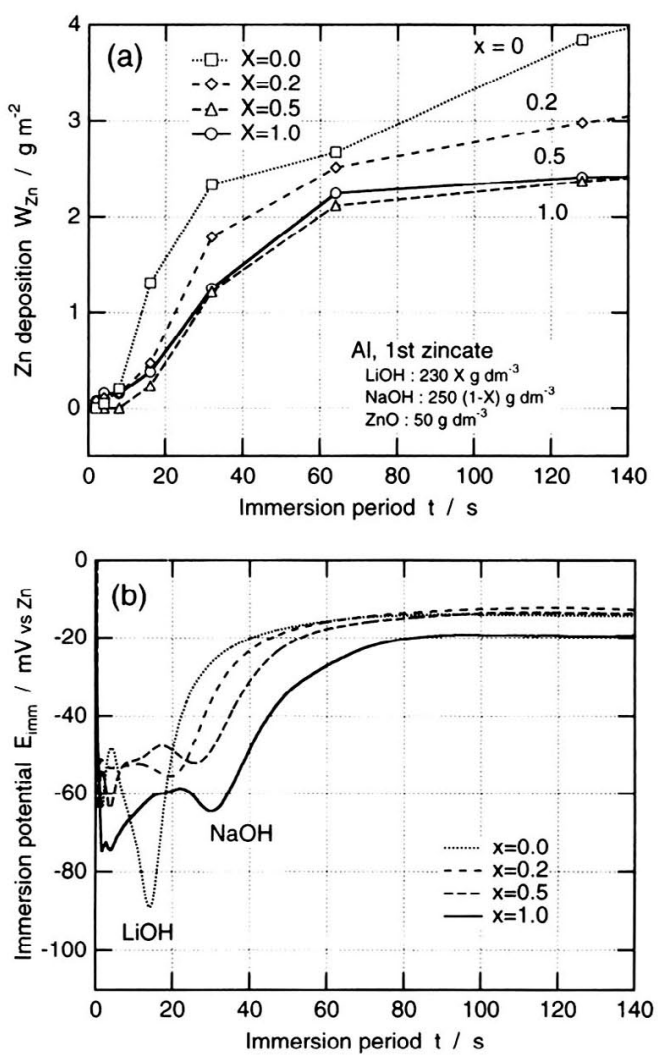

Fig. 8 Zn deposition on $\mathrm{Al}$ (a) and immersion potential (b) during the 1 st and the 2 nd zincate processes as a function of immersion period in zincate solutions prepared by mixing zincate solutions $\mathrm{A}$ and $\mathrm{D}$.

ンケート溶液に $\mathrm{LiOH}$ を添加して自由水分子を減らす と, 置換反応の遅れならびに抑制効果が見られるはずで

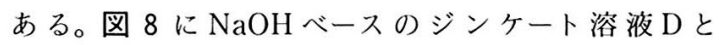
$\mathrm{LiOH}$ ベースのジンケート溶液 $\mathrm{A}$ を混合して置換反応 を行った結果を示す。溶液 $\mathrm{A}$ の割合が 0.5 程度までは 溶液 $\mathrm{A}$ と類似の $\mathrm{Zn}$ 析出挙動となり, 置換反応が抑制さ れた。また割合が 0.2 程度でも溶液 D と比べて置換速 度はかなり遅い。これらの結果は, ジンケート溶液に含 まれる $\mathrm{Li}^{+}$が多数の水分子を配位することにより, 溶液 の構造化をもたらすとする上述のモデルを支持するよう に思える。

\section{4. 結論}

(1) $\mathrm{LiOH}$ ベースのジンケート溶液では, $\mathrm{NaOH}$ ベース のジンケート溶液と比較して置換反応の遅れがみられた。 これは, $\mathrm{Li}^{+}$に対する水分子の配位数が大きいため, 水 溶液中の自由水分子が隇少して $\mathrm{OH}^{-}$の活量係数が低下 し, Al 溶解反応が抑制されたためと思われる。

(2) $\mathrm{LiOH}$ ベースのジンケート溶液では, $\mathrm{Al}$ 表面が $\mathrm{Zn}$ 
で置換された段階で置換反応速度が大きく低下した。こ れは, 自由水分子が減少したため $\mathrm{Zn}(\mathrm{OH})_{4}{ }^{2-}$ に対する 水分子の配位数が減少して配位球が小さくなり, $\mathrm{Al}$ と の間の電子移動が容易となって Zn 析出が迅速に進行し たためと思われる。 $\mathrm{Al}$ 表面が $\mathrm{Zn}$ で速やかに被覆され ることにより $\mathrm{Al}$ 溶解が抑制され, 置換反応速度が低下 する。

(3) $\mathrm{NaOH}$ ベースのジンケート溶液に $\mathrm{LiOH}$ を添加する ことにより，置換反応を抑制できた。これは，溶液中の 自由水分子が $\mathrm{Li}^{+}$に配位することにより減少し，(1)(2)と 同様の効果が得られたためと思われる。

(4) $\mathrm{LiOH}$ ベースのジンケート溶液に Fe(III) を添加する と, 置換反応の抑制効果が失われた。これは, $\mathrm{Fe}$ が $\mathrm{Zn}$ 上に共析して Zn の析出・成長を阻害するため, 析出 $\mathrm{Zn}$ がち密化するとともに, $\mathrm{Al}$ 表面の完全な被覆が損な われて $\mathrm{Al}$ 露出面からの溶解が持続したためと推定され る。

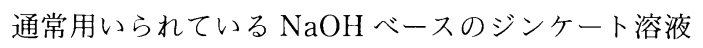
による置換処理では, 置換反応による $\mathrm{Al}$ 溶解が持続す るため処理時間などの管理が重要である。たとえばガラ スなどの基板上に形成された $\mathrm{Al}$ 薄膜の微細な配線に対 するめっき前処理では, $\mathrm{Al}$ 溶解量が多いとパターンそ のものが溶解消失してしまうこともある。これに対して $\mathrm{LiOH}$ ベースの溶液では $\mathrm{Al}$ 表面が $\mathrm{Zn}$ で置換された段 階で置換反応速度がかなり低下して $\mathrm{Al}$ 表面の過剰溶解
が抑制される。微細化・精密化の時代に対応しためっき 技術の開発に有用な知見となれば幸いである。

\section{謝辞}

本研究を遂行するにあたり, $\mathrm{Al}$ 試料を提供頂いた高 橋英明氏 (北海道大学大学院 工学研究科教授), 水溶液 中の水の構造に関してご教授頂いた田村紘基氏 (北海道 大学大学院 工学研究科助教授)に謝意を示します。

(Received July 29, 1999 ; Accepted November 19, 1999)

\section{文献}

1 ）田代雄彦, 千葉国雄, 福田 豊, 中尾英弘, 本間英夫 ; 表面技 術, 45, 720 (1994)

2) 安住和久, 瀬尾眞浩, Leonard Nanis：表面技術，47，529 (1996)

3 ) 安住和久, 藤重祐介, 瀬尾且浩, Leonard Nanis, 中尾英弘, 田 代雄彦；表面技術, 47, 802（1996）

4）矢部 賢；表面技術, 48, 522（1997）

5 ) 中田 毅, 和田一郎, 今井八郎, 池島賢司, 井上晃一郎, 渡辺 徹 ; 表面技術, 48, 820（1997）

6 ）斉藤昌弘, 中山郁雄；表面技術, 48, 982 (1997)

7 ) 安住和久, 藤重祐介, 瀬尾眞浩, Leonard Nanis, 中尾英弘, 田 代雄彦：表面技術, 48, 1019 (1997)

8 ）化学便覧 基礎編 II（改定 3 版）, 日本化学会編（丸善, 1984）

9) G. O. Mallory : Plating and Surface Finishing, 72, (6), (1985)

10) Robertson, S. G. and Ritchie, I. M. ; J. Appl. Electrochem., 27, 799 (1997) 